\title{
Elucidation of physico-chemical characteristics and mycoflora of bovine milk available in selected area of Karachi, Pakistan.
}

\section{${ }^{* 1}$ RUBINA PERWEEN; ABBAS BHUTTO; DARAKHSHAN ARA; S.SHAHID SHAUKAT; QAMAR-UL HAQ}

\author{
${ }^{I}$ Department of Chemistry, Federal Urdu University of Arts, Science and Technology, Karachi \\ ${ }^{2}$ Pakistan Agriculture Research Council, Karachi University \\ ${ }^{3}$ Institute of Environmental Studies, University of Karachi, Pakistan. \\ * RUBINA PERWEEN: r_perween1@yahoo.com,ABBAS BHUTTO: mabbasbhutto@gmail.com \\ DARAKHSHAN ARA: ara_ahmed@hotmail.com,S.SHAHID SHAUKAT: shahid_shaukat2007@yahoo.co.uk, QAMAR-UL HAQ: \\ drqhaq@gmail.com
}

Key words: physical characteristics, essential elements, toxic elements, fungal species

\begin{abstract}
ISO 14000 has opened the field for enhancing the awareness towards healthy environment and gives the ideology of regular assessment of threshold values not only of nutrients but contaminants as well. Under this statement microbiological studies in terms of mycoflora followed by physical characteristics and level of some essential elements $\mathrm{Mg}, \mathrm{Fe}$, $\mathrm{Cu}$ and $\mathrm{Zn}$, and deleterious metal $\mathrm{Cd}$ were analyzed in fresh milk samples (FMS) and tetra pack milk or UHT processed milk samples (PMS) available in Gulshan-e-Iqbal Town, Karachi for the residents. Samples were collected in the morning time during winter season. Physical parameters like $\mathrm{pH}$, conductivity, density, viscosity, surface tension and refractive index were observed very soon after sample collection. Percentage of ash and total dissolved solids (TDS) were also measured. For fungal flora studies PDA (Potato Dextrose Agar) and Sabourouds Agar were used for the fungal growth. The concentrations of metals considered were estimated after wet digestion of samples using atomic absorption spectroscopy. The ranges of average concentration of $\mathrm{Mg}, \mathrm{Fe}, \mathrm{Cu}$ and $\mathrm{Zn}$ were found to be $77.120-141.915 \mathrm{mg} / \mathrm{l}, 0.580-7.320 \mathrm{mg} / \mathrm{l}, 0.004-0.070 \mathrm{mg} / \mathrm{l}$ and $2.574-$ $4.872 \mathrm{mg} / \mathrm{l}$. The level of $\mathrm{Cd}$ was estimated in the samples between $0.0050-0.053 \mathrm{mg} / \mathrm{l}$, but was not observed in most of the samples. Among the fungi, the highest diversity was that of Aspergillus spp. that produces aflatoxins. CJASEM
\end{abstract}

DOI: http:/ / dx.doi.org/10.4314/jasem.v17i2.9

Milk is a multinutritive substantial diet in food commodities because of its valuable ingredients ideally quantized makes it precious alone or a part of food globally. In developed countries cow's milk is normally supplied to consumers, while in Pakistan buffalo is the major source of milk production. An average composition of bovine milk is $87.2 \%$ water, $3.7 \%$ fat, $3.5 \%$ protein, $4.9 \%$ lactose and $0.7 \%$ mineral oxides (Mc Graw-Hill, 2005). Minerals have many important functions in our body. They assist in fluid regulation and energy production, are essential to the health of our bones and blood, and help rid in our body of deleterious by-product of metabolism (Thompson and Manore, 2009).

Recent investigations on epidemics have established the correlation among the pertaining of numerous diseases in humans significantly neurological disorder, heart and kidney diseases, several types of carcinogenic diseases and persistence of heavy metals like $\mathrm{Cd}, \mathrm{Cr}, \mathrm{Hg}$ and $\mathrm{Ni}$ (Xia et al., 1988 and Goldberg et al., 1990). It is well known that toxins are excreted through milk and transfer from cow to human via milk or milk products. Toxic metals chemically identical to $\mathrm{Ca}$ such as $\mathrm{Pb}$ are also passed into milk (Klaassen,
2001). Children are less tolerant to lead than adults, which especially affects on their central nervous system and bone synthesis (Werner, 1989). Muhammad et al., (2009) and Aslam et al., (2010) reported that high levels of deleterious heavy metals $(\mathrm{Cd}, \mathrm{Cr}, \mathrm{Ni}$ and $\mathrm{Pb})$ were estimated in bovine milk available in the premises of Faisalabad, Pakistan, even higher than daily intake level.

Enhancement of threats against health throughout the globe compels the researchers to rationalize facts. It is unsuspected fact that the environment of Karachi is ideally suited for the growth of different types of allergens particularly those responsible for superficial mycoses and intermediate mycoses (Mughal, 2002 and Nester et al., 2004). Recently Rao et al., (2009) has identified aflatoxins producing fungi prevailing in the atmosphere of Karachi city and various kinds of fungal species such as Aspergillus niger, Aspergillus wentii, Alternaria solani, Drechslera dematioidea and Penicillium notatum were found in the atmosphere of the area close to Gulshan-e-Iqbal Town. Egyetem and Kar (2004) highlighted the injurious influence of fungi on Hungarians which are strictly related to the consumption of mycotoxins contaminated edibles 
including Hungarian bovine milk. In spite of this enzyme lysozyme, in milk protein has an antifungal activity but its function is greatly affected by the fluctuation of concentration of electrolytes and trace elements (Benkerroum, 2008). In addition to the tolerable limit of aflatoxins in milk as the Federal Law of food safety in USA by the FD\&C Act is $<0.5 \mathrm{ng} / \mathrm{g}$ (Klaassen, 2001). Polovinski-Horvatovic et al., (2009) reported that $30 \%$ of raw bovine milk samples available in Serbia was contaminated by aflatoxins that exceed this limit and also mentioned the same for Slovenia, $10 \%$ bovine milk samples exhibited the aflatoxin concentration above the tolerable limit

Milk available in Gulshan-e-Iqbal town through various sources such as milk vendor shops and direct sellers on smaller level comparatively. Milk is supplied to these shops mostly from cattle colonies found in suburbs of Karachi city and small dairy farms existed in surrounding areas of town. Whereas UHT treated tetra packs milk of all brands also available in which two companies (Nestle and Engrofoods) have lion's share in processed milk marketing. Lacking in development of application of modern technology, uneducated workers at these dairy farms, believe on the primitive procedure limits them to develop a concept towards better hygiene thus many adulterants enter to the fresh milk from the initial stage i.e. milking. The maintenance of the freshness and enhancement of volume of low quality milk is generally carried out by the addition of ice or water. Wide exposures of heavy metals in the environment unbalance the mineral level and increases the heavy metal level diminish the milk quality. These contaminants also alter the physico-chemical characteristics of milk (Javaid et al., 2009). In these circumstances, investigation of physico-chemical properties of milk is necessary to provide a clue of toxication

In current studies physico-chemical analysis and identification of fungal species have been carried out subsequently, focused nutritive and toxic factors of milk available in Gulshan-e-Iqbal Town and evaluate to what extent these contaminants present and compared samples.

\section{MATERIALS AND METHOD}

Random sampling was carried out from the different milk shops including fresh milk samples (FMS) and UHT processed tetra pack milk samples (PMS) of various brands. Consequently sufficient number of FMS from the milk shops and PMS of various brands from general stores of different locations in Gulshan-e-Iqbal Town were purchased in the morning hours, during winter season. The FMS were taken in the polyethene bags as the fresh milk administrated to public, in contrast PMS in tetra packs and transported to the laboratory for analysis and stored by the frozen to $-20^{\circ} \mathrm{C}$ analysis after physical properties examination until required.

Physical parameters were determined immediately just after the samples transported to the laboratory. The $\mathrm{pH}$, conductivity, total dissolve solid was examined by $\mathrm{HACH}$ Sension 105 multi parameter by direct immerse the electrode in the samples. Whereas specific gravity, viscosity and surface tension determination through classical procedures R.D bottle, viscometer and stalagmometer respectively. Ash of each sample was calculated by drying a known volume of each sample at $105{ }^{\circ} \mathrm{C}$ on hot plate and then ignites in the muffle furnace at $550{ }^{\mathrm{O}} \mathrm{C}$ for 2 hours, 3hours and 4 hours according to the standard method (AOAC, 2000). Constant weight was appeared after 2 hours.

For the analysis of nutritional elements and toxic elements, the samples were digested according to low cost digestion method (Mehmood et al., 2004). All milk samples were treated with concentrated HNO3 in 2:1 sample to acid ratio, heated on the preheated hot plate at $105{ }^{\mathrm{O}} \mathrm{C}$ for 45 minutes or until the solution became transparent. The cold clear samples solution filtered in $100 \mathrm{ml}$ volumetric flask and made the volume up to the mark with distilled water. These digested samples were labeled as stock solution and diluted whenever required with distilled water. A blank was also prepared similarly under identical conditions.

Heavy metals including toxic metals as well estimated through Atomic Absorption Spectrophotometer (AAS). For this purpose a VARIAN-220 FS Atomic Absorption Spectrophotometer equipped with auto sampler whereas standard burner and air-acetylene was applied as fuel. For radiation source of respective metal standard hollow cathode lamps were used.

Fungal isolation: Isolation of fungal species from milk samples including FMS and PMS has been found out through culture media Petri plate method. For this task Potato dextrose agar and Sabourouds dextrose agar were synthesized for the growth spores of various fungal existed in milk samples. Little aliquots $(1 \mathrm{ml})$ of every sample was inoculated triply in each media Petri plates and incubated at room temperature $\left(30-40^{\circ} \mathrm{C}\right)$ for $5-8$ days. After growing of fungi's spores characterization was

\section{RUBINA PERWEEN; ABBAS BHUTTO; DARAKHSHAN ARA; S.SHAHID SHAUKAT; QAMAR-} UL HAQ 
made by means of morphological and microscopic properties with the help of these manuals (Ellis 1971; 1976; Barnett and Hunter 1972; Nelson et al., 1983; Domsch et al., 1980; Singh et al., 1991; Sutton 1980).

\section{RESULT AND DISCUSSION}

The average values of physicochemical characteristics of FMS and PMS (6.5\% fat) and literature values of bovine milk are depicted in Table 1 . The $\mathrm{pH}$ is a measure of the sample's acidity or basicity, the specific gravity related to the water contents of the sample and the conductivity determines the concentration of electrolytes and dissolved ions present in the sample (Imran et al., 2008; Hanrahan, 2012).

The $\mathrm{pH}$, specific gravity and refractive index of FMS and PMS are found in the ranges 5.75-6.72, 1.0172-1.0371 and 1.342-1.351 respectively. The literature range of $\mathrm{pH}$ in Table1 indicates the freshness of milk as the freshly drawn milk exhibits $\mathrm{pH}$ in this range. The least $\mathrm{pH}$ value has been shown by FMS3 and FMS5 but more than that value where the coagulation and putrification started i.e. 4.9 (Fennema, 1996), whilst FMS6 has shown highest $\mathrm{pH}$ value, approximately $64 \%$ samples met the standard value.

The lower values of specific gravity as compared to that reported in literature were observed in FMS2 and FMS6 while identical refractive index value of these two samples have been recorded. Similarity was also noted in PMS1 and PMS2; about73\% samples exhibited the value of specific gravity within the standard range. $\sim 64 \%$ samples have shown within the literature range of refractive index, while $18 \%$ samples showed below and the same percentage greater refractive index as compared to that reported in literature.

The range of conductivity of samples at a particular temperature has been measured as $2.36 \mathrm{mS} / \mathrm{cm}$ $5.70 \mathrm{mS} / \mathrm{cm}$. The minimum conductivity was shown by FMS2, whereas maximum conductivity was recorded by FMS7. All samples exhibited lower conductivity than the reported limits in literature as mentioned in Table 1 . The viscosity and surface tension of the samples has been observed in the ranges $1.39 \mathrm{mpa}-2.2906 \mathrm{mpa}$ and $50.4120 \mathrm{Dynes} / \mathrm{cm}-$ 54.0523 Dynes/cm respectively. However $\sim 82 \%$ samples have exhibited the values of these two parameters within the literature range. The lesser value of viscosity as compared to literature value has been shown by the FMS2 and FMS6, while
PMS1 showed highest viscosity. The least measurement of surface tension has been shown by FMS2 while greatest value was shown by PMS1. According to Table 1, it is found that most of the samples including FMSs and PMSs show higher values of surface tension than standard value.

The amount of total oxides of minerals in FMSs and PMSs are mentioned in Table 1 as percentage of ash. FMS6 showed least ash level amongst all the samples either FMSs or PMSs, although 91\% samples met the standard value.

Table 2 manifested the average concentration of metals with standard deviation at the confidence level 95\% $(\mathrm{p} \leq 0.05)$ in the milk samples (FMSs and PMSs) available in Gulshan-e-Iqbal Town, Karachi, for the consumption of local inhabitant. The choice of relatively small area for sampling is convenient to sort out the contamination more precisely. It is uncontestable fact that accumulation of metals either nutritional or toxic in the milk greatly influenced by the environmental circumstances where the cattle raised, feed they intake, procedure of milking either manual or mechanical and areal exposure of the milk in container at shops etc (Sarwar et al., 2002).

The level of $\mathrm{Mg}$ in the samples were estimated in the range $77.120-141.915 \mathrm{mg} / 1$, only $18 \%$ samples showed more than the level reported in literature, whereas 54\% samples were close to the literature value. FMS6 has least concentration of $\mathrm{Mg}$ where as FMS8 shows highest level and PMSs have shown the level within the range.

The concentration of iron was found in the range of $0.580-7.320 \mathrm{mg} / \mathrm{l}$. The lowest concentration was measured in FMS3 while the PMS2 exhibited highest level of iron among the samples even literature value. This exclusive value of PMS2 indicates the iron fortification of sample which is in accordance to the value mentioned on packet. It is believed that $\mathrm{Ca}$ and $\mathrm{P}$ substantially decrease iron absorption by up to $70 \%$ (Hallberg et al., 1991). In fact, milk has trace amount of iron (Thompson et al., 2008 ), in this regard bioavailability of iron is higher in fortified milk compared to unfortified milk. However, PMS2 has sufficient level as recommended daily allowance (RDA) proposed by The National Academy of Science 2001 i.e. $7 \mathrm{mg} /$ day for the toddlers age group 1-3years. Nevertheless, other samples have higher concentration than those reported in the literature though they did not match the least requirement of $\mathrm{RDA}$. The concentration of $\mathrm{Cu}$ in all samples was

\section{RUBINA PERWEEN; ABBAS BHUTTO; DARAKHSHAN ARA; S.SHAHID SHAUKAT; QAMAR-} UL HAQ 
estimated in the range of $0.004-0.07 \mathrm{mg} / \mathrm{l}$ but lower than the reported in available literature value as represented in Table 2. The lowest level was found in FMS1 whereas highest level was observed in FMS8. National Academy of Science suggested the $\mathrm{Cu}$ intake for adults is $0.9 \mathrm{mg} /$ day with an upper limit is $10 \mathrm{mg} /$ day (Thompson and Manore, 2009). In comparison of daily requirements all milk itself does not a better source to provide the adequate amount of copper.

The evaluated levels of Zinc have been shown in Table 2 in the range of $2.574-4.872 \mathrm{mg} / \mathrm{l}$, about $64 \%$ samples exhibited more or less close to that of literature level as depicted in Table 2. In contrast, $36 \%$ samples showed below the literature level; while FMS6 has least concentration. The RDA from the age >1yaer to 8years is in the range of 3$5 \mathrm{mg} /$ day according to The National Academy of Science 2001. It is concluded that milk supplies the Zinc requirement to some extent.

From Table 2 the concentration of Cadmium was estimated in the range of $0.005-0.053 \mathrm{mg} / \mathrm{l}$ and approximately in $54 \%$ samples cadmium was not detected or found below the detection limit. Cadmium has been measured 33\% in FMSs while $100 \%$ in PMSs.

The percentages of various fungal species found in milk samples are mentioned in Table3. Seven fugal species (Aspergillus candidus, A. flavus, A. fumigatus, A. niger, A. terreus, Mucor mucedo and Rhizopus stolonifer) were isolated in FMSs collected randomly from Gulshan-e-Iqbal Town, whereas two fungal species (A. flavus and A. niger) was isolated in PMSs available in this town. The FMS4 and FMS6 and FMS7 (27\% samples) have exhibited maximum number of fugal species while $54 \%$ samples have three fungal species. The fungus Aspergillus was found to be multifarious in comparison to others fungi. It is the major toxogenic fungi (D’Mello and Macdonald, 1997) that produces aflatoxins which are mycotoxins produced as carcinogenic, teratogenic and mutagenic secondary metabolites (Frisvad et al., 2005). A. niger was recovered in $\sim 91 \%$ percent samples, A. flavus detected in $\sim 82 \%$ samples and Rhizopus stolonifer found in $36.36 \%$ samples. A. candidus, $A$. fumigatus, A. terreus and $M$. mucedo were recorded in $27.27 \%$ samples. In contrast, $100 \%$ PMSs have shown $A$. flavus and $A$. niger. The significant presence of $A$. flavus and A. niger in the milk samples provides clear evidence of airborne fungal contamination is the most susceptible in milk and these species are identical to the airborne fungal flora of Karachi which have been reported by Rao et al., (2009). Mycoflora of bovine milk was investigated by Jodral et al., (Apr. 1993) that four genera of fungi namely Aspergillus, Fusarium, Geotrichum and Penicillium isolated in milk samples available in Span either in raw milk or UHT processed milk. The presence of fungal spores in processed milk is responsible of post pasteurization specifically packaging (Hui, 1992). Similar study has been done by Torkar et al. (Nov. 2008) and isolated four fungal genera (Aspergillus, Fusarium, Mucor and Penicillium) in considerable percentage of Slovenia cattle milk.

Conclusion: This study highlighted that more work is required in the area of packaging material that permits the deleterious metals and fungal spores. Aspergillus sp. (A. flavus and A. niger) were recorded in most of the milk samples. The results also revealed that mycotoxogenic fungus cannot be avoidable from milk even from processed milk. Further, it is noteworthy that the addition of healthy ingredients (fortification) gives better results.

Acknowledgement: This research work was done in LDPE (Laboratory of Dandrochronology and Plant Ecology) and Research Laboratory of Plant Pathology and aerobiology. Authors are grateful to Dr. Moinuddin Ahmed, director of LDPE to facilitate present research work and obliged as well to Grain Quality Testing Laboratory (GQTL), Pakistan Agriculture Research Council, Karachi University to provide technical support in estimation of nutrition/toxic metals 
Table 1: Average values of Physico-chemical characteristics of milk samples.

\begin{tabular}{|c|c|c|c|c|c|c|c|c|}
\hline S.No. & $\mathrm{pH}$ & $\begin{array}{c}\text { Specific } \\
\text { gravity }\end{array}$ & $\begin{array}{l}\text { Refractive } \\
\text { Index }\end{array}$ & Conductivity & $\begin{array}{l}\text { Temper } \\
\text { ature }\end{array}$ & Viscosity & $\begin{array}{l}\text { Surface } \\
\text { tension }\end{array}$ & Ash \\
\hline & & & & $(\mathrm{ms} / \mathrm{cm})$ & ${ }^{\circ} \mathrm{C}$ & Mpa & Dynes/cm & $\%$ \\
\hline FMS1 & 6.45 & 1.0286 & 1.346 & 3.13 & 21.3 & 1.5844 & 51.0321 & 0.69 \\
\hline FMS2 & 6.23 & 1.0172 & 1.342 & 2.36 & 20.3 & 1.3929 & 50.4120 & 0.70 \\
\hline FMS3 & 5.75 & 1.0299 & 1.344 & 3.39 & 20.3 & 1.5642 & 50.8215 & 0.68 \\
\hline FMS4 & 6.51 & 1.0283 & 1.348 & 4.87 & 22.0 & 1.5773 & 51.6378 & 0.71 \\
\hline FMS5 & 5.75 & 1.0307 & 1.347 & 5.42 & 24.1 & 1.6985 & 51.7583 & 0.71 \\
\hline FMS6 & 6.72 & 1.0185 & 1.342 & 4.30 & 24.3 & 1.3944 & 51.1457 & 0.49 \\
\hline FMS7 & 6.13 & 1.0333 & 1.349 & 5.70 & 25.2 & 1.9124 & 53.0420 & 0.80 \\
\hline FMS8 & 6.54 & 1.0298 & 1.344 & 4.90 & 25.4 & 1.6057 & 50.6129 & 0.69 \\
\hline FMS9 & 6.59 & 1.0251 & 1.348 & 3.71 & 25.0 & 1.6373 & 51.4771 & 0.68 \\
\hline $\mathrm{PMS}^{*} 1$ & 6.40 & 1.0348 & 1.351 & 4.76 & 21.7 & 2.2906 & 54.0523 & 0.71 \\
\hline $\mathrm{PMS}^{*} 2$ & 6.42 & 1.0371 & 1.351 & 5.23 & 22.0 & 1.8223 & 51.9316 & 0.69 \\
\hline Lit & $\begin{array}{l}6.30- \\
7.50 \mathrm{a}\end{array}$ & $1.028-1.032 \mathrm{a}$ & $\begin{array}{l}1.3440- \\
1.3485 \mathrm{~b}\end{array}$ & $6.50-11.00 \mathrm{c}$ & & $1.53-3.33 \mathrm{a}$ & $50 \mathrm{~b}$ & $\begin{array}{l}0.68- \\
0.74 d\end{array}$ \\
\hline \multicolumn{9}{|c|}{$\begin{array}{l}\text { *: tetra pack milk sample } \\
\text { Lit: a. Mahmood et al., (2004). } \\
\text { b. Hui, (1992). } \\
\text { c. Imran et al., (2008). } \\
\text { d. Fennema, (1996) }\end{array}$} \\
\hline
\end{tabular}

Table: 2 Average levels of metals in milk samples

\begin{tabular}{|l|l|l|l|l|l|}
\hline Sample no. & Mean concentration $\mathrm{mg} / \mathrm{l} \pm \mathrm{SD}$ & $\mathrm{Cu}$ & $\mathrm{Zn}$ & $\mathrm{Cd}$ \\
\hline \multirow{3}{*}{ FMS1 } & $\mathrm{Mg}$ & $\mathrm{Fe}$ & $0.004 \pm 0.001$ & $4.800 \pm 0.002$ & ND \\
\cline { 2 - 6 } & $124.158 \pm 0.002$ & $2.100 \pm 0.130$ & $0.005 \pm 0.024$ & $2.670 \pm 0.050$ & $\mathrm{ND}$ \\
\hline FMS2 & $83.210 \pm 0.023$ & $2.083 \pm 0.005$ & $0.015 \pm 0.002$ & $3.200 \pm 0.004$ & $0.032 \pm 0.003$ \\
\hline FMS3 & $125.688 \pm 0.004$ & $0.580 \pm 0.201$ & $0.030 \pm 0.001$ & $4.462 \pm 0.021$ & $\mathrm{ND}$ \\
\hline FMS4 & $128.365 \pm 0.015$ & $3.260 \pm 0.040$ & $0.020 \pm 0.001$ & $4.540 \pm 0.001$ & ND \\
\hline FMS5 & $127.171 \pm 0.068$ & $0.840 \pm 0.001$ & $0.006 \pm 0.032$ & $2.574 \pm 0.011$ & ND \\
\hline FMS6 & $77.120 \pm 0.002$ & $1.350 \pm 0.021$ & $0.010 \pm 0.004$ & $4.872 \pm 0.002$ & $0.053 \pm 0.001$ \\
\hline FMS7 & $141.915 \pm 0.030$ & $1.530 \pm 0.002$ & $0.070 \pm 0.001$ & $3.890 \pm 0.003$ & $0.005 \pm 0.002$ \\
\hline FMS8 & $137.105 \pm 0.001$ & $3.163 \pm 0.005$ & $0.005 \pm 0.005$ & $3.830 \pm 0.040$ & ND \\
\hline FMS9 & $124.050 \pm 0.001$ & $1.524 \pm 0.024$ & $0.025 \pm 0.001$ & $3.200 \pm 0.001$ & $0.025 \pm 0.002$ \\
\hline PMS1 & $125.611 \pm 0.006$ & $0.833 \pm 0.001$ & $0.010 \pm 0.020$ & $4.078 \pm 0.022$ & $0.032 \pm 0.004$ \\
\hline PMS2 & $90.145 \pm 0.016$ & $7.320 \pm 0.005$ & $0.09 \mathrm{~b}$ & $4.000 \mathrm{~b}$ & \\
\hline Lit & $130 \mathrm{a}$ & & &
\end{tabular}

$$
\begin{gathered}
* * \text { : Not Detected } \\
\text { Lit: }
\end{gathered}
$$

a. Hui, (1992).

b. Gropper et al., (2005).

\begin{tabular}{|c|c|c|c|c|c|c|c|}
\hline Sample no. & Aspergillus candidus & $\begin{array}{l}\text { Aspergillus } \\
\text { flavus }\end{array}$ & $\begin{array}{l}\text { Aspergillus } \\
\text { fumigates }\end{array}$ & Aspergillus niger & Aspergillus terreus & Mucor mucedo & Rhizopus stolonifer \\
\hline Fms1 & -- & 8.333 & -- & 75 & 8.333 & 8.333 & -- \\
\hline Fms2 & -- & 26.66 & -- & 60 & -- & 13.33 & -- \\
\hline Fms3 & -- & 28.57 & -- & 14.28 & -- & -- & 57.14 \\
\hline Fms4 & 05.88 & 52.94 & -- & 35.29 & -- & 05.88 & -- \\
\hline Fms5 & 33.33 & 33.33 & -- & 33.33 & -- & -- & -- \\
\hline Fms6 & -- & 14.28 & 14.28 & 14.28 & -- & -- & 57.14 \\
\hline Fms7 & 14.28 & -- & 35.29 & -- & 14.28 & -- & 36.15 \\
\hline Fms8 & -- & 26.66 & -- & 05.88 & -- & -- & 67.46 \\
\hline Fms9 & -- & -- & 26.66 & 46.66 & 26.66 & -- & -- \\
\hline Pms1 & -- & 67.21 & -- & 32.79 & -- & -- & -- \\
\hline Pms2 & -- & 71.00 & -- & 29.00 & -- & -- & -- \\
\hline
\end{tabular}

Table: 3 Percentage of fungal species isolated from milk samples 


\section{REFERENCES}

AOAC Official Methods of Analysis, (2000). Dairy Products. AOAC International, chapter 33, p. 10.

Aslam, B., Javed, I., Khan, F.H. and Rehman, Z., (2010). Uptake of Heavy Metal Residues from Sewerage Sludge in the Milk of Goat and Cattle during Summer Season. Pakistan Veterinary Journal, 31(1): 75-77.

Barnett, H.L., Hunter, B.B., (1972). Illustrated Genera of Imperfect Fungi. Burgess Publishing Co., Minneapolis, Minnesota, 241 p.

Benkerroum, N., (29 December 2008). Review: Antimicrobial activity of lysozyme with special relevance to milk. African Journal of Biotechnology. 7(25): 4856-4867.

D’Mello, J.P.F. and Macdonald A.M.C., (1997). Mycotoxins. Animal Feed Science and Technology. 69: 155-166.

Domsch, K.H., Gams, W. and Anderson, T.H., (1980). Compedium of Soil Fungi. Volume I. Eching, IHW-Verlag. 860 p.

Egyetem, K., and Kar, A., (22 Aug. 2004). Nutrition health aspects of mycotoxins. Orv Hetil. 145 (34): 1739-46.

Ellis, E.B., (1976). More Dematiaceous Hyphomycetes. Commonwealth Mycological Institute, Kew, UK: 507 p.

Ellis, M.B., (1971). Dematiacicious Hyphomycetes. CMI., Kew Surrey, England, 608 p.

Fennema O.R., (1996). Food Chemistry. $3^{\text {rd }}$ ed. Owen R. Fennema. Chapter no. 14.

Frisvad J.C., Skouboe P., Samson R.A., (2005). Taxonomic comparison of three different groups of aflatoxin producers and a new efficient producer of aflatoxin B1, sterigmatocystin and 3-Omethylsterigmatocystin, Aspergillus rambellii sp. Systematic and Applied Microbiology, 28, 442-453.

Goldberg S.J., Lebowitz M.D., Graver E.J. and Hicks S., (1990). An association of human congenital cardiac malformation and drinking water contaminants. J. Am. Coll. Cardiol. 16, $155-164$
Hallberg, L., Brune, M., Erlandsson, M., Sandberg, A.S. and Hulten, R.L., (1991). Calcium: effect of different amounts on nonheme and hemeiron absorption in humans. American Journal of Clinical Nutrition, 53: 112-19.

Hanrahan, G., (2012). Key Concept in Environmental Chemistry. Academic Press, Elsevier, Chapter 4, 135 p.

Hui, Y. H., (1992). Encyclopedia of food science and technology. John Wiley \& Sons Inc. USA. 3: 1796-1799.

Imran M., Khan, H., Hassan, S.S. and Khan, R., (July, 2008). Physico-chemical characteristics of various milk samples available in Pakistan. Journal of Zhejiang University Science B, 9(7): $546-551$.

Javaid, S. B., Gadahi, J. A., Khaskheli, M., Bhutto, M.B., Kumbher, S. and Panhwar, A.H., (2009). Physical and chemical quality of market milk sold at Tandojam, Pakistan. Pakistan Veterinary Journal. 29 (1): 27-31.

Jodral, M., Linan, E., Acosta, I., Gallego, C., Rojas, F. and Bentabol, A., (Apr. 1993). Mycoflora and Toxigenic Aspergillus flavus in Spanish milk. International Journal of Food Microbiology. 18 (2): 171-4.

Klaassen, C.D., (2001). Casarett and Doull's Toxicology the Basic Science of Poisons. $6^{\text {th }}$ ed. Mc Graw-Hill, Medical Publishing Division, USA. 1054 p.

Mahmood, F., Akhtar, M., Javed, I., Rehman, Z., Jan I., Anwar, M.I. and Hayat S., (2009). Quantitative structure activity relationship and risk analysis of some heavy metal residues in milk of cattle and goat. Toxicology and Industrial Health. 25(3): 177-81.

Mahmood, F., Niazi, S.B., Raza, A. and Khokhar, M.Y., (2004). Physico-analytical Studies on Commercial Milk Samples. Journal of Chemical Society of Pakistan. 26(3): 212-216.

Mc Graw-Hill, (2005). Concise Encyclopedia of Science and Technology. $5^{\text {th }}$ ed.1402.

Mughal, F.H., (2002). Effect of air pollutants. Dawn, Feb. 20 ${ }^{\text {th }}$. Karachi, Pakistan. 
Nelson, P.E., Toussoun, T.A. and Marasas W.F.O. (1983). Fusarium species: an illustrated manual for identification. The Pennsylvania State Uni. Press, 193 p.

Nester, E.W., Anderson, D.G., Roberts, C.E., Nancy, J. N., Martha, P., Nester, T. and Hurley, D., (2004). Microbiology A Human Perspective. $4^{\text {th }}$ ed. Mc Graw-Hill. 311 p.

Polovinski-Horvatovic, M., Juric, V. and Glamocic, D., (2009). Two year study of Aflatoxin $\mathbf{M}_{1}$ in milk in the region of Serbia. Institute for Animal Husbandry, Belgrade-Zemun. Biotechnology in Animal Husbandry 25(5-6): 713-718.

Rao, T.A., Shaikh, A.H. and Ahmed M., (2009). Airborne fugal flora of Karachi, Pakistan. Pakistan Journal of Botany. 41(3): 1421-1428.

Sareen, G.S., Jack, S.L. and James, G.L., (2005). Advanced Nutrition and Human Metabolism. $4^{\text {th }}$ ed. Thomson Wadsworth, USA. 436,446 p.

Sarwar, M., Khan, M.A., Nisa, M. and Iqbal, Z., (2002). Review Dairy Industry in Pakistan: A Scenario. International Journal of Agriculture and Biology, 4(3): 420-428.

Singh, K., Frisvad, J.C., Thrane, U., Mathur, S.B., (1991). An Illustrated Manual of dentification of Some Seed-borne Aspergilli, Fusaria, Penicillia and their Mycotoxins. Danish Govt. Inst. Seed Path. for Dev. Count., Ryvangs Allc 78, DK-2900 Hellerup, Denmark. 133 p.
Sutton, B.C., (1980). The Coelomycetes (CAB, IMI) Kew, Surrey, U.K. 696 p.

Thompson, J. and Manore, M., (2009). Nutrition An Aapplied Approach. $2^{\text {nd }}$ ed.Pearson Benjamin Cummings. New York, 13 p.

Thompson, L.J., Manore, M.M. and Vaughan A.L., (2008). The Science of Nutrition. Pearson Benjamin Cummings, New York. 728 p.

Torkar, K.G., and Teger, S.G., (Nov. 2008). The Microbiological Quality of Raw Milk after Introducing the Two Day's Milk Collecting System. Acta agriculturae Slovenica. 92(1): 6174.

Werner, M., (1989). Handbook of clinical chemistry. CRC Press, Inc. Boca Raton, Florida. 4: 238 p.

Xia, L.W.; Liang, S.X., Jiang, J.W., Zhou, X.J. and $\mathrm{Li}, \mathrm{J} .$, (1988). Trace element content in drinking water of nasopharyngeal carcinoma patients. Cancer Lett. 41, 91-97. 